\title{
Major Mammary Pathogens as Contributors to Total Bacterial Counts in Raw Milk
}

\author{
Dušan Ryšánek ${ }^{1}$, Monika Zouharová1, Vladimír Babák ${ }^{1}$ \\ ${ }^{1}$ Department of Immunology, Section of Pathophysiology of Mammary Gland, \\ Veterinary Research Institute, Brno, Czech Republic
}

Received November 6, 2008

Accepted February 9, 2009

\begin{abstract}
The purpose of this study was to assess the contribution of major mammary pathogens, as well as of coliform and Gram-negative non-coliform bacteria to standard plate counts (SPCs) of bulk tank milk samples (BTMSs). Randomly selected anonymous BTMSs were collected from 268 dairy herds (with approximately 29,000 cows) in the Czech Republic during 2007. The most frequently detected pathogens were found to be E. faecalis $\left(16.1 \%\right.$; geometric mean $9.8 \times 10^{2}$ $\mathrm{CFU} / \mathrm{ml})$ and $S$. uberis $\left(13.6 \% ; 9.0 \times 10^{2} \mathrm{CFU} / \mathrm{ml}\right)$. Highly significant positive correlations $(P<$ $0.01)$ between the bacterial counts of the dominant pathogens and the relevant SPC were found for E. faecalis and $S$. dysgalactiae, as were significant correlations $(P<0.05)$ for $S$. uberis, $E$. faecium, and $S$. aureus. Highly significant positive correlations $(P<0.01)$ were found between SPC and coliform count and between SPC and Gram-negative non-coliform bacteria count. The results suggest, therefore, a recent dominance of environmental pathogens especially streptococci and enterococci, over contagious mammary pathogens in BTMSs. The geometric means of SPC in BTMSs with mammary pathogen $\left(7.7 \times 10^{4} \mathrm{CFU} / \mathrm{ml}\right.$ for environmental; $7.4 \times 10^{4} \mathrm{CFU} / \mathrm{ml}$ for contagious pathogens) exceed significantly $(P<0.05)$ the geometric means of SPC of pathogen free BTMSs $\left(4.4 \times 10^{4} \mathrm{CFU} / \mathrm{ml}\right)$. This study revealed that the major mammary pathogens contribute significantly to SPCs of BTMSs.
\end{abstract}

Bulk tank milk samples, mammary pathogen count, standard plate count, coliform bacteria count, Gram-negative non-coliform bacteria count

The standard plate count (SPC) of bulk tank milk samples (BTMSs) is the most widely accepted criterion for measuring milk quality in all milk-producing countries throughout the world. For example, both in Europe and the USA, SPC hygienic limit values are codified (Anonymous 2006; FDA 2001). Regulation No. 1662/2006 (Anonymous 2006) requires the SPC at $30{ }^{\circ} \mathrm{C}$ to be less than $1.0 \times 10^{5} \mathrm{CFU} / \mathrm{ml}$ for raw cows' milk. In the USA, the Pasteurized Milk Ordinance (FDA 2001) states that, to qualify as grade A milk, bacterial counts shall not exceed $1.0 \times 10^{5} \mathrm{CFU} / \mathrm{ml}$. Since early $1990 \mathrm{~s}$, researchers, progressive dairy producers, veterinarians and dairy health consultants have been interested in BTMSs analysis as a tool both to determine milk quality and to troubleshoot herds for mastitis (Jayarao et al. 2004).

In general, microbial contamination of raw milk occurs from three main sources: from within the udder, from the exterior of the udder, and from the surface of milk handling and storage equipment (Bramley and McKinnon 1990; McKinnon et al. 1990; Jayarao and Wolfgang 2003). The health and hygiene of the cow are both important in influencing the level of microbial contamination of raw milk. Equally important are the temperature and length of time in storage (which allows microbial contaminants to multiply) and the types of bacteria present in bulk raw milk. Although there is often only one source of bacteria that causes high bulk tank counts, high bacteria counts can also result from a combination of factors (Murphy and Boor 2007).

Foot-note:

Staphylococcus aureus subsp. aureus - in text only S. aureus

Streptococcus dysgalactiae subsp. dysgalactiae- in text only S. dysgalactiae

Address for correspondence:

MVDr. Dušan Ryšánek, CSc.

Veterinary Research Institute

Hudcova 70

62100 Brno, Czech Republic
Phone: +420533331501

Fax: +420541211229

E-mail: rysanek@vri.cz

http://www.vfu.cz/acta-vet/actavet.htm 
Mammary gland pathogens have been a focus of interest as important contributors to the bacterial count in BTMS for many years, having been studied by Bramley et al. (1984), Hayes et al. (2001), Jayarao et al. (2004), Zadoks et al. (2004), and Howard (2006). The mastitis organisms most often found to influence the total bulk milk bacteria count are Streptococcus spp., followed by coagulase-negative staphylococci (CNS) and coliforms (Bramley and McKinnon 1990; Hayes et al. 2001; Zadoks et al. 2004; Howard 2006).

Mammary gland pathogens can be listed in groups: major or minor, contagious or environmental (Fox and Gay 1993; Harmon 1994). Of the major pathogens, Streptococcus uberis, Streptococcus bovis, enterococci, coliforms, Pseudomonas spp., and Arcanobacterium pyogenes are classified as environmental. Staphylococcus aureus, Streptococcus agalactiae, Streptococcus dysgalactiae, coagulase-positive staphylococci, Staphylococcus intermedius, and Mycoplasma bovis are classified as contagious. The majority of these pathogens are considered in this study.

Although the total plate count was less than $5.0 \times 10^{4} / \mathrm{ml}$ in raw milk from $81.5 \%$ of suppliers in the Czech Republic during 2003 (Anonymous 2004), for example, the legal limit has been exceeded in some cases. Therefore, the aim of this study was to clarify the proportions and bacterial counts of major mastitis pathogens in BTMSs and their relationships to SPC values. The purpose was to judge the contributions of these pathogens and groups of coliform and Gram-negative non-coliform bacteria to SPCs in BTMSs in order to improve microbial quality of raw milk intended for dairy processing.

\section{Materials and Methods}

Experimental design

During January to July and September to November 2007, BTMSs were collected from 268 dairy herds (with approximately 29,000 cows) on regular test days scheduled for raw milk hygienic quality determination.

The anonymous dairy herds were randomly selected over a 3-week test-day interval with a limitation of 30 herds per test day. The plate counts for specific major mammary gland pathogens and the SPCs were determined. In addition, coliform bacteria counts (CCs) and Gram-negative non-coliform bacterial counts (NCs) were undertaken. Staphylococcus aureus, other coagulase-positive staphylococci (CoPS), S. agalactiae and S. dysgalactiae were grouped as contagious pathogens while S. uberis, Escherichia coli, Pseudomonas aeruginosa, Enterococcus faecalis and Enterococcus faecium were grouped as environmental pathogens, according to categorization by Fox and Gay (1993) and by Harmon (1994).

Correlations were calculated for the bacterial counts of the relevant pathogens or groups of bacteria against SPCs.

Sampling procedure

All BTMSs intended for checking the hygienic quality of raw milk were collected in accordance with the European Standard EN ISO 707:1997 (Anonymous 1997) using auto-samplers (AutoSampler, Foss Electric, Hillerød, Denmark). All samples were collected by specially trained technicians from the bulk tank milk of raw milk suppliers. Samples were transported without a preservative reagent to the laboratory in polystyrene boxes containing freezer packs and examined immediately upon arrival. The technical design of the polystyrene boxes prevents the samples from becoming frozen.

\section{Microbiological examination}

The cultivation procedure was performed as per Jayarao et al. (2004). The milk samples were thoroughly mixed by gently inverting the milk vial 20 to 25 times. One millilitre of milk was transferred to a sterile tube containing $9 \mathrm{ml}$ of sterile phosphate buffered saline (Sigma, Saint Louis, Missouri, USA). The 10-fold diluted sample was then vortexed at high speed for $15 \mathrm{~s}$, and $50 \mu 1$ was plated onto both selective and non-selective media.

Plate count agar (HIMEDIA, Mumbai, India) and incubation for $72 \mathrm{~h}$ at $30{ }^{\circ} \mathrm{C}$ were used for enumeration of the SPC. CC was determined as lactose-positive colonies on MacConkey's agar no. 3 (MCA) (Oxoid, Hampshire, UK) whilst NC was determined as a count of lactose-negative colonies on MCA. Escherichia coli were also determined on MCA. Streptococci counts were estimated using modifiedEdward's medium (Oxoid) supplemented with colistin sulphate and oxolinic acid (Sawant et al. 2002). Baird Parker agar (Oxoid) was used to determine the number of staphylococci. Plates for enumeration were incubated at $37^{\circ} \mathrm{C}$ for $48 \mathrm{~h}$. Cetrimide agar (Merck, Darmstadt, Germany) with an incubation period of $48 \mathrm{~h}$ at $35^{\circ} \mathrm{C}$ was used for isolation of P. aeruginosa. 
Colonies suggestive of S. aureus and CoPS from Baird Parker agar were randomly selected, streaked onto 5\% sheep blood agar (BA) (Blood Agar Base No. 2, HIMEDIA, Mumbai, India) and incubated for $24 \mathrm{~h}$ at $37{ }^{\circ} \mathrm{C}$. Colonies expressing both typical and atypical (without zones of lipolysis and proteolysis) appearances were taken into consideration. The isolates were examined for haemolysis, catalase production, and for free coagulase using the tube coagulase test (ITEST, Hradec Kralove, Czech Republic). Coagulase-positive strains were examined using the Voges-Proskauer test for production of acetoin (VPtest, PLIVA-Lachema, Brno, Czech Republic) and were finally identified using STAPHYtest (PLIVA-Lachema).

Colonies suggestive of S. agalactiae, S. uberis, S. dysgalactiae, E. faecalis and E. faecium on Edward's agar supplemented with colistin sulphate and oxolinic acid were randomly selected, streaked onto BA and then incubated for $24 \mathrm{~h}$ at $37^{\circ} \mathrm{C}$. All isolates were examined for haemolysis and catalase production, differentiated using the CAMP-Esculin Test (NMC 1999), and their growth capabilities assessed on agar containing $6.5 \% \mathrm{NaCl}$ and on agar containing 4\% oxgall (OX-BILE desiccated, OXOID) (equivalent to 40\% bile). The isolates were classified in Lancefield groups using the latex agglutination test (ITEST STREPTO GROUP, ITEST). A test for detection of pyrrolidonyl arylamidase (PYRtest, PLIVA-Lachema) was conducted and the isolates were identified using the STREPTOtest (PLIVA-Lachema).

Colonies suggestive of $E$. coli on MCA were subcultured onto BA and incubated for $24 \mathrm{~h}$ at $37{ }^{\circ} \mathrm{C}$. The isolates were examined for oxidase production (OXItest, PLIVA-Lachema), citrate utilization (Simmons citrate agar, Merck), lactose, sucrose and dextrose fermentation (Triple Sugar Iron Agar, Merck), and motility (Motility Test Medium, HIMEDIA, Mumbai, India). After their assessment, a test for detecting $\beta$-glucuronidase and indol (COLItest, PLIVA-Lachema) was also carried out.

Colonies suggestive of $P$. aeruginosa on Cetrimide agar were subcultured onto BA and, after $24 \mathrm{~h}$ incubation at $37^{\circ} \mathrm{C}$, they were examined for oxidase production, citrate utilization, and lactose, sucrose and dextrose fermentation, as well as for motility (see above for media).

Bacterial count of specific pathogen was determined from percentage of verified colonies analogically as described in European Standard EN ISO 6888-1, 1999.

We used specific bacterial pathogen counts to determine the dominant pathogens (i.e. the bacterial species with the highest count, where two or more bacterial species were detected), and these formed the basic units for this study.

Statistical analysis

In order to be able to work with normally distributed data, SPCs, CCs, NCs and the bacterial counts of specific pathogens were adjusted using a logarithmic transformation (log base 10).

All statistical analyses were performed using the GraphPrism 5 for Windows software package (GraphPad Software Inc., San Diego, CA, USA).

The significance of differences between SPCs from BTMSs that were mammary pathogen-free and BTMSs containing contagious or environmental pathogens was assessed using unpaired $t$-test.

The dependency between the bacterial counts of specific pathogens and SPCs, as well as between SPCs and CCs or NCs, was expressed using Pearson's correlation coefficient (r). The significance of the respective correlation coefficients was verified by testing the null hypothesis $r=0$.

\section{Results}

Mammary pathogens were detected in $77.4 \%$ of BTMSs, and $22.6 \%$ of the samples were pathogen-free. Table 1 summarizes the proportions and bacteria counts of the major mammary pathogens detected in BTMSs. The total proportion of BTMSs contaminated by environmental pathogens dominated over samples that were pathogen-free or contaminated by contagious pathogens. The most frequently detected pathogens were E. faecalis and $S$. uberis, whilst CoPS, E. faecium and $S$. agalactiae occurred with the lowest frequency. Based on the bacteria counts, the highest count was detected for E. faecalis and followed by $S$. uberis. The results suggest, therefore, a recent dominance of environmental pathogens, especially streptococci and enterococci, over contagious mammary pathogens in BTMSs. The geometric means of these bacteria count did not, however, exceed $1.0 \times 10^{3} \mathrm{CFU} / \mathrm{ml}$.

As shown in Table 2, significantly higher $(P<0.05)$ values of SPC were detected for the contagious and environmental pathogen categories than in the case of pathogen-free samples.

Highly significant positive correlations $(P<0.01)$ were determined between the bacterial counts of dominant pathogens and the relevant SPCs for E. faecalis and $S$. dysgalactiae, as well as significantly positive correlations $(P<0.05)$ for $S$. uberis, E. faecium and $S$. aureus (Table 3). 
Table 1. Proportions and bacterial counts of dominant mammary pathogens in bulk tank milk samples

\begin{tabular}{|c|c|c|c|c|c|}
\hline Dominant pathogen & $\begin{array}{c}\text { Number of } \\
\text { samples }\end{array}$ & $\begin{array}{c}\text { Proportion }^{\mathrm{a}} \\
{[\%]}\end{array}$ & $\begin{array}{c}\log \mathrm{Mean}^{\mathrm{b}} \\
{[\log \mathrm{CFU} / \mathrm{ml}]}\end{array}$ & $\begin{array}{c}\mathrm{SD}^{\mathrm{c}} \\
{[\log \mathrm{CFU} / \mathrm{ml}]}\end{array}$ & $\begin{array}{l}\text { GMean }^{\mathrm{d}} \\
{[\mathrm{CFU} / \mathrm{ml}]}\end{array}$ \\
\hline Pathogen-free & 63 & 22.6 & & & \\
\hline Streptococcus agalactiae & 8 & 2.9 & 2.66 & 0.41 & 454 \\
\hline Staphylococcus aureus & 32 & 11.5 & 2.53 & 0.32 & 340 \\
\hline Coagulase-positive staphylococci & 4 & 1.4 & 2.04 & 0.66 & 109 \\
\hline Streptococcus dysgalactiae & 35 & 12.5 & 2.66 & 0.58 & 462 \\
\hline Subtotal (Contagious) & 79 & 28.3 & & & \\
\hline Streptococcus uberis & 38 & 13.6 & 2.96 & 0.62 & 903 \\
\hline Enterococcus faecalis & 45 & 16.1 & 2.99 & 0.58 & 982 \\
\hline Enterococcus faecium & 7 & 2.5 & 2.51 & 0.34 & 324 \\
\hline Escherichia coli & 19 & 6.8 & 2.00 & 0.95 & 101 \\
\hline Pseudomonas aeruginosa & 28 & 10.0 & 1.47 & 0.59 & 29 \\
\hline Subtotal (Environmental) & 137 & 49.1 & & & \\
\hline
\end{tabular}

a $-100 \%=279$ (in 11 cases two pathogens showed the same CFU values)

b - Arithmetic means for logarithmic transformed data

c - Standard deviation for logarithmic transformed data

d - Back-transformed (i.e. geometric) means

Table 2. Descriptive statistics and significance of differences for standard plate counts of the Free, Contagious, and Environmental pathogen categories in bulk tank milk samples

\begin{tabular}{|l|c|c|c|c|c|}
\hline Category of samples & $\begin{array}{c}\text { Number of } \\
\text { samples }\end{array}$ & $\begin{array}{c}\text { Range } \\
{[\log \text { CFU/ml }]}\end{array}$ & $\begin{array}{c}\log \text { Mean } \\
{[\log \text { CFU/ml }]}\end{array}$ & $\begin{array}{c}\text { SD }^{\mathrm{b}} \\
{[\log \text { CFU/ml }]}\end{array}$ & $\begin{array}{c}\text { GMean }^{\mathrm{c}} \\
{[\mathrm{CFU} / \mathrm{ml}]}\end{array}$ \\
\hline Overall & 268 & $3.4-6.3$ & $4.83 \mathrm{~A}$ & 0.64 & $6.8 \times 10^{4}$ \\
\hline Pathogen-free & 63 & $3.4-6.3$ & $4.65 \mathrm{~B}$ & 0.68 & $4.4 \times 10^{4}$ \\
\hline Contagious $^{\mathrm{d}}$ & 77 & $3.9-6.3$ & $4.87 \mathrm{~A}$ & 0.58 & $7.4 \times 10^{4}$ \\
\hline Environmental $^{\mathrm{e}}$ & 132 & $3.7-6.3$ & $4.89 \mathrm{~A}$ & 0.64 & $7.7 \times 10^{4}$ \\
\hline
\end{tabular}

a - Arithmetic means for logarithmic transformed data (the presence of different capital letters indicates statistical significance, i.e. two-tailed $P$-value for unpaired $t$-test was $<0.05)$

$\mathrm{b}$ - Standard deviation for logarithmic transformed data

c - Back-transformed (i.e. geometric) means

d - Samples contaminated with a contagious pathogen as dominant

e - Samples contaminated with an environmental pathogen as dominant

Table 3. Correlation between bacterial count of dominant pathogens and standard plate count

\begin{tabular}{|l|c|c|}
\hline Dominant pathogen & $\begin{array}{c}\text { Pearson's correlation } \\
\text { coefficient (r) }\end{array}$ & $P^{\mathrm{a}}$ \\
\hline Streptococcus agalactiae & -0.573 & 0.137 \\
\hline Staphylococcus aureus & 0.414 & $0.019^{*}$ \\
\hline Coagulase-positive staphylococci & 0.691 & 0.309 \\
\hline Streptococcus dysgalactiae & 0.537 & $0.001^{* *}$ \\
\hline Streptococcus uberis & 0.328 & $0.045^{*}$ \\
\hline Enterococcus faecalis & 0.524 & $<0.001^{* *}$ \\
\hline Enterococcus faecium & 0.796 & $0.032^{*}$ \\
\hline Escherichia coli & 0.442 & 0.058 \\
\hline Pseudomonas aeruginosa & 0.175 & 0.374 \\
\hline
\end{tabular}

a - Two-tailed $P$-value for null hypothesis $\mathrm{r}=0\left({ }^{*} P<0.05\right.$; $\left.{ }^{* * *} P<0.01\right)$
There were highly significant positive correlations $(P<0.01)$ between SPC and both $\mathrm{CC}$ and NC Gram-negative categories (Tables 4 and 5). It means in other words that increasing SPCs in BTMSs could be accompanied by high contamination with coliform bacteria and/or Gram-negative non-coliform bacteria.

\section{Discussion}

The purpose of this study was to assess the recent contribution of major mammary pathogens and 
Table 4. Descriptive statistics for standard plate count, coliform bacteria count and Gram-negative non-coliform bacteria count in bulk tank milk samples

\begin{tabular}{|l|c|c|c|c|c|}
\hline Characteristic & $\begin{array}{c}\text { Number of } \\
\text { samples }\end{array}$ & $\begin{array}{c}\text { Range } \\
{[\text { bacteria/ml }]}\end{array}$ & $\begin{array}{c}\log \mathrm{Mean}^{\mathrm{a}} \\
{[\log \text { bacteria/ml }]}\end{array}$ & $\begin{array}{c}\mathrm{SD}^{\mathrm{b}} \\
{[\log \text { bacteria/ml }]}\end{array}$ & $\begin{array}{c}\mathrm{GMean}^{\mathrm{c}} \\
{[\text { bacteria/ml } /}\end{array}$ \\
\hline Standard plate count & 268 & $2.4 \times 10^{3}-2 \times 10^{6}$ & 4.83 & 0.64 & $6.8 \times 10^{4}$ \\
\hline Coliform bacteria count & 201 & $10-1.5 \times 10^{4}$ & 2.18 & 0.83 & 151 \\
\hline Non-coliform bacteria count & 209 & $10-1.5 \times 10^{4}$ & 2.19 & 0.78 & 155 \\
\hline
\end{tabular}

a - Arithmetic means for logarithmic transformed data

b - Standard deviation for logarithmic transformed data

c - Back-transformed (i.e. geometric) means

Table 5. Correlation between standard plate count and coliform and Gram-negative non-coliform bacteria counts

\begin{tabular}{|l|c|c|}
\hline Correlation & $\begin{array}{c}\text { Pearson's correlation } \\
\text { coefficient (r) }\end{array}$ & $P^{\mathrm{a}}$ \\
\hline SPC vs. $\mathrm{CC}^{\mathrm{b}}$ & 0.370 & $<0.001^{\text {** }}$ \\
\hline SPC vs. $\mathrm{NC}^{\mathrm{c}}$ & 0.411 & $<0.001^{\text {*** }}$ \\
\hline
\end{tabular}

a - Two-tailed $P$-value for null hypothesis $\mathrm{r}=0\left({ }^{* *} P<0.01\right)$

$\mathrm{b}$ - Correlation between standard plate count and coliform bacteria count

c - Correlation between standard plate count and Gram-negative non-coliform bacteria count coliform and Gram-negative noncoliform bacteria to SPCs in BTMSs in the Czech Republic, and thereby to contribute to improving the future quality of raw milk intended for dairy processing. This study revealed that the most important contributors to elevated SPCs in BTMSs are streptococci and enterococci such as E. faecalis and S. uberis, along with E. faecium and S. dysgalactiae.

These results are to a great extent in accordance with findings by other authors. Bramley et al. (1984) noted that high counts of mastitis pathogens in herd bulk milk samples were detected for herds with high incidence of S. uberis mastitis. Hayes et al. (2001) found S. uberis to be the predominant organism in BTMSs with SPCs ranging from $1.4 \times 10^{4}$ to $6.0 \times 10^{5} \mathrm{CFU} /$ $\mathrm{ml}$. Zadoks et al. (2004) found that streptococci, staphylococci and Gram-negative bacteria, respectively, accounted for $69 \%, 3 \%$, and $3 \%$ of total bacterial count variability, whilst the most commonly identified streptococcal species were S. uberis, Aerococcus viridans, and S. agalactiae, detected in $81 \%, 50 \%$, and $31 \%$ of 48 bulk tank samples, respectively. How ard (2006) noted counts of $>1.0 \times 10^{3} \mathrm{CFU} / \mathrm{ml}$ for total aesculin-positive streptococci, CNS, and coliforms in $48 \%, 51 \%$, and $11 \%$ of BTMSs, respectively. Finally, Murphy and Boor (2007) noted that, although other mastitis pathogens have the potential to influence the bulk tank count, Streptococcus spp., and most notably S. agalactiae and S. uberis, are the mastitis organisms that most often influence the total bulk milk count.

The significant correlation between the $S$. aureus counts in BTMSs and SPCs in this study was somewhat surprising. S. aureus is not thought to be a frequent contributor to total bulk tank counts (Murphy and Boor 2007). Zadoks et al. (2004) found that staphylococci accounted for only $3 \%$ of total bacterial count variability. Howard (2006) also found that, unlike the counts of aesculin-positive streptococci, counts for $S$. aureus were rather low, ranging from zero to $1.0 \times 10^{3} \mathrm{CFU} / \mathrm{ml}$. In our study, however, we determined a positive correlation between $S$. aureus counts and SPC, despite low $S$. aureus counts (geometric mean $=3.4 \times 10^{2} \mathrm{CFU} / \mathrm{ml}$ ).

This study revealed counts (geometric means) of SPC of $6.8 \times 10^{4} / \mathrm{ml}$ and of CC and $\mathrm{NC}$ of 151 and $155 \mathrm{CFU} / \mathrm{ml}$ in 201 (75\%) and 209 (78\%) of 268 samples, respectively. Jayarao et al. (2004) had observed a CC count of $70 \mathrm{CFU} / \mathrm{ml}$ and a count of $200 \mathrm{CFU} /$ $\mathrm{ml}$ for NC; concurrent SPCs ranged from $1.8 \times 10^{2}$ to $6.3 \times 10^{4} / \mathrm{ml}$. In another study from Pennsylvania (USA) between 2000 and 2001, Jayarao et al. (2001) reported that 126 BTMSs displayed $56 \% \mathrm{SPC}<5 \times 10^{3} / \mathrm{ml}, 19 \%$ at $5 \times 10^{3}$ to $1 \times 10^{4} / \mathrm{ml}$, and $25 \%>1 \times$ $10^{4} / \mathrm{ml}$. In general, it is accepted that $\mathrm{CC}>100 \mathrm{CFU} / \mathrm{ml}$ suggests poor hygienic practice (Jayarao and Wolfgang 2003). 
This study revealed a high positive correlation between SPC and CC, as well as between SPC and NC. This finding corresponds only partly with the findings presented by Jayarao et al. (2004), who found that BTMSs with means NC $>200 \mathrm{CFU} / \mathrm{ml}$ were 6 times more likely to have medium SPCs and 4 times more likely to have high SPCs as compared with BTMSs with $\mathrm{NC}<200 \mathrm{CFU} / \mathrm{ml}$. On the other hand, these authors have determined the lack of a relationship between CC and SPC. Hayes et al. (2001) stated, however, that E. coli in particular has been shown to elevate bacteria counts in BTMSs.

Finally, it must be mentioned that the detection of such pathogens does not necessarily indicate that they originated from cows with mastitis. Potential environmental mastitis pathogens can occur in milk as a result of such other contributing factors as dirty cows, poor cleaning of equipment, and/or inadequate cooling of raw milk. An accompanying elevated somatic cell count, however, can sometimes serve as supportive evidence that mastitis may, especially unapparent mastitis, have caused an increase in the bulk milk bacteria count (Ryšánek and Babák 2005; Ryšánek et al. 2007; Murphy and Boor 2007).

In conclusion, the results of this study reveal that the most important recent contributors to elevated SPCs in BTMSs in the Czech Republic are streptococci and enterococci, especially $E$. faecalis along with $S$. uberis and E. faecium. S. aureus appears to be an important contributor to SPC from among contagious mammary pathogens. Based on correlation analysis, the most important contributors were E. faecalis and $S$. dysgalactiae, followed by $S$. uberis, E. faecium, $S$. aureus and the CC and NC categories of Gramnegative bacteria. This suggests that the healthy mammary gland is of equal importance as suitable environmental hygienic conditions for high quality of raw milk intended for dairy processing.

\section{Podílejí se hlavní patogeny mléčné žlázy skotu na celkovém počtu mikroorganismů v syrovém mléce?}

Záměrem této studie bylo zhodnotit, zda hlavní patogeny mléčné žlázy a zda rovněž koliformní (KB) a Gram negativní nekoliformní bakterie (NK) přispívají k celkovému počtu mikroorganismů (CPM) bazénových vzorků mléka (BV). Ve 268 českých mléčných stádech (přibližně s 29000 krav) byly v r. 2007 náhodně vybrány anonymní BV. Nejčastěji detekovanými patogeny byly E. faecalis $\left(16,1 \%\right.$; geometrický průměr $9,8 \times 10^{2} \mathrm{CFU}$ $/ \mathrm{ml})$ a $S$. uberis $\left(13,6 \% ; 9,0 \times 10^{2} \mathrm{CFU} / \mathrm{ml}\right)$. Vysoce signifikantní pozitivní korelace $(P<0.01)$ mezi bakteriálními počty dominantních patogenů a př́slušnými CPM byla prokázána pro E. faecalis a $S$. dysgalactiae, zatím co signifikantní korelace $(P<0.05)$ pro $S$. uberis, E. faecium a $S$. aureus. Vysoce signifikantní pozitivní korelace $(P<0.01)$ byla prokázána mezi CPM a KB a mezi CPM a NK. Výsledky tedy dokládají soudobou dominanci environmentálních patogenů, zejména streptokoků a enterokoků nad kontagiózními patogeny mléčné žlázy v BV. Geometrické průměry CPM u vzorků, ve kterých byly zachyceny patogeny mléčné žlázy $\left(7,7 \times 10^{4} \mathrm{CFU} / \mathrm{ml}\right.$ pro environmentální; $7,4 \times 10^{4} \mathrm{CFU} /$ $\mathrm{ml}$ pro kontagiózní patogeny) převyšují významně $(P<0.05)$ geometrické průměry CPM v bazénových vzorcích prostých patogenů $\left(4,4 \times 10^{4} \mathrm{CFU} / \mathrm{ml}\right)$. Tato studie odhalila, že hlavní patogeny mléčné žlázy významně přispívají k CPM v BV mléka.

\section{Acknowledgment}

The present work was supported by the Ministry of Agriculture of the Czech Republic (Grant No. MZE 0002716201). The authors express their thanks to Miss Libuše Spěváková for technical assistance.

\section{References}

Anonymous 1997: Milk and milk products - Guidance on sampling. European Standard (EN ISO 707) 1997. Geneva, Switzerland: International Organization for Standardization. 
Anonymous 2004: Evaluation of raw milk quality in the central laboratories of Czech Republic. Association of the Central Laboratories for the Raw Milk Quality Evaluation. Praha 2004. 20 p.

Anonymous 2006: Commission Regulation (EC) No 1662/2006 amending Regulation (EC) No 853/2004 of the European Parliament and of the Council laying down specific hygiene rules for food of animal origin. Brussels, Belgium: The Commission of the European Communities. L 320/1, 10 p.

Bramley AJ, Mckinnon CH, Staker RT, Simpkin DL 1984: The effect of udder infection on the bacterial flora of the bulk milk of ten dairy herds. J Applied Bacteriol 57: 317-323

Bramley AJ, Mckinnon CH 1990: The microbiology of raw milk. In: Robinson RK (Ed.), Dairy Microbiol, Vol. 1, Elsevier Science Publishers, London, pp. 163-208

FDA 2001: Grade "A" Pasteurized Milk. Ordinance 2001 Revision May 15, 2002, Section 6. The Examination of Milk and Milk Products. Washington, DC, USA: U.S. Department of Health and Human Services; U.S. Food and Drug Administration; Center for Food Safety and Applied Nutrition.

Fox LK, Gay JM 1993: Contagious mastitis. Vet Clin North Am: Food Anim Practice 9: 475-487

Harmon RJ 1994: Physiology of mastitis and factors affecting somatic cell counts. J Dairy Sci 77: 2103-2112

Hayes MC, Ralyea RD, Murphy SC, Carey NR, Scarlett JM, Boor KJ 2001: Identification and characterization of elevated microbial counts in bulk tank raw milk. J Dairy Sci 84: 292-298

Howard P 2006: Mastitis pathogens present in bulk tank milk from seven dairy herds in the Waikato region, New Zealand. NZ Vet J 54: 41-43

Jayarao BM, Pillai SR, Wolfgang DR, Griswold DR, Hutchinson LJ 2001: Herd level information and bulk tank milk analysis: Tools for improving milk quality and udder health. Bovine Practitioner 35: 23-35

Jayarao BM, Wolfgang DR 2003: Bulk-tank milk analysis. A useful tool for improving milk quality and herd udder health. Vet Clin North Am: Food Anim Practice 19: 75-92

Jayarao BM, Pillai SR, Sawant AA, Wolfgang DR, Hegde NV 2004: Guidelines for monitoring bulk tank milk somatic cell and bacterial counts. J Dairy Sci 87: 3561-3573

McKinnon CH, Rowlands GJ, Bramley AJ 1990: The effect of udder preparation before milking and contamination from the milking plant on bacterial numbers in bulk milk of eight dairy herds. J Dairy Res 57: $307-318$

Murphy SC, Boor KJ 2007: Sources and causes of high bacteria counts in raw milk: An abbreviated review. http://www.extension.org/pages/Sources_and_Causes_of_High_Bacteria_Counts_in_Raw_Milk:_An_ Abbreviated Review

NMC 1999, National Mastitis Council. 1999. Laboratory Handbook on Bovine Mastitis. Rev. Edition, National Mastitis Council, Inc., Madison, 222 p.

Rysanek D, Babak V 2005: Bulk tank milk somatic cell count as an indicator of the hygiene status of primary milk production. J Dairy Res 72: 400-405

Rysanek D, Babak V, Zouharova M 2007: Bulk tank milk somatic cell count and sources of raw milk contamination with mastitis pathogens. Vet Med Czech 52: 223-230

Sawant AA, Pillai SR, Jayarao BM 2002: Evaluation of five selective media for isolation of catalase-negative gram-positive cocci from bulk tank milk. J Dairy Sci 85: 1127-1132

Zadoks RN, Gonzalez RN, Boor KJ, Schukken YH 2004: Mastitis-causing streptococci are important contributors to bacterial counts in raw bulk tank milk. J Food Prot 67: 2644-2650 